\title{
A conceptual model for integrating strategic supply management into the supply chain
}

\section{Eva Ponce-Cueto*, Álvaro García-Sánchez and Miguel Ortega-Mier}

Department of Industrial Engineering and Management, Technical University of Madrid (UPM),

Escuela Técnica Superior de Ingenieros Industriales (ETSII),

C/José Gutiérrez Abascal 2 - 28006, Madrid, Spain

Fax: +34913363207

E-mail: eva.ponce $(\bar{a})$ upm.es

E-mail: alvaro.garcia@upm.es

E-mail: niguel $($ )etsii.upm.es

${ }^{\star}$ Corresponding author

\begin{abstract}
In this paper, a strategic supply management reference model for supplier integration in the supply chain is presented. The model developed is based on the comparative case study of two relevant industries - antomotive and aircraft - and may be suitable for other industries. The survey and the subsequent analysis of these industries have confirmed the strategic importance of supplies and the need for an inlegrated approach of supply management, both in terms of internal processes and of extemal suppliers. Additionally, the study has proved that there is not a unique model for supply management, valid for all industries.
\end{abstract}

Keywords: supply management; reference model; strategic outsourcing; manufacturer-supplier relationship; supplier integration; Spanish case study.

Reference to this paper should be made as follows: Ponce-Cucto, E., García-Sánchez, A. and Ortega-Mier, M. (2010) 'A conceptual model for integrating strategic supply management into the supply chain', Int. J. Manufocturing Technology and Management, Vol. 19, Nos. 1/2, pp. 102-123.

Biographical notes: $\mathrm{E}$. Ponce-Cueto received her $\mathrm{PhD}$ in Industrial Engineering from Carlos III University of Madrid in 2002. Her dissertation has received two awards with special distinction in the Spanish context. She is currently an Associate Professor at the Department of Industrial Enguneering, Business Administration and Statistics, Technical University of Madrid (UPM), Madrid, Spain. His current research interest includes supplier relationship, supply management, integraled supply chains and closed-loop supply chams.

Á. García-Sánchez fïnished his $\mathrm{PhD}$ in Industrial Engineering at the Technical University of Madrid (UPM) in 2007. Currently, he is an Assistant Professor at the Department of Industrial Engineering, Business Administration and Statistics, Teclunical University of Madrid (UPM), Madrid, Spain. His main areas of interest are discrelc-event simulation, quanlitative modelling, supplier relationship and supply management. 
M. Ortega-Mier finished his $\mathrm{PhD}$ in Industrial Engineering at the Technical University of Madrid (UPM) in 2007. He is currently an Assistant Professor at the Department of Industrial Engineering, Business Administration and Statistics, Technical University of Madrid (UPM), Madrid, Spain. His current research interest includes supplier relatiouship, supply manageneut, optimisation, metaheuristics and simulation.

\section{Introduction}

Companies have had to face radical changes in recent years; technological advances, global markets and growing competition (Merli, 1994; Lamming, 1993) have driven company managers to modify their business practices to meet the demands of their customers. Price and quality are no longer enough to compete in today's markets. Delivery time, customised service, agility and flexibility are critical factors in an increasingly competitive market in which products are notoriously short-lived (Heberling, 1993; Fisher, 1997; Christopher, 2000). Business strategies have changed accordingly.

The trend towards outsourcing has led to new sorts of relationships between manufacturers and suppliers, relationships that require collaboration between companies if they are to provide the right products and services with competitive standards (Lanming, 1993; Ellram and Billingion, 2001; Pyke and Johnson, 2003). These trends have led companies to rethink their supply concepts and practices to address the more complex relationships with all those involved in the product and service at multiple levels. Therefore, integration across the supply chains is one of the main challenges for the future and may even become essential for the companies to survive.

In the $1970 \mathrm{~s}$, companies were mainly concemed with economic factors when deciding whether to make or buy (Coase, 1937; Willianson, 1975). This short-term approach used to lead to adopting vertical integration strategies, thus, under-rating the quality, logistic and technical aspects in which customers ane interested and, moreover, being less and less capable of responding to rising demands of quality and market service standards.

More recent decision-1naking approaches have been put forth. Prahalad and Hamel (1990) present a new theory with a strategic approach. This theory advises companies to concentrate on those activities in which they are essentially competent (referred to as 'core competences'), outsourcing the rest. Numerous publications have enlarged the literature advocating this trend termed 'strategic outsourcing' (Venkatesan, 1992; Quinn and Hilmer, 1994).

The wide adoption of outsourcing in industries has led to changes in procurement. First, the number of items purchased is larger (Schary and Skjott-Larsen, 2001); additionally, they are of greater strategic importance and complexity (Gadde and Hakansson, 1994). This has considerably affected companies' supply management. The strategic importance of this management was recognised in the 1980s by different authors (Spekman, 1981; Burt and Soukup, 1985; Reck and Long, 1988; Heberling, 1993), and it gradually evolved (slowly, in the opinion of Ellram and Carr (1994)) from a purely administrative function (Ansoff, 1970) to a logistic process that had to be coordinated and properly managed (Towill, 1997; Handfield and Nichols, 1999; Lee, 2002). 
A supply chain management approach involves integration coordination and collaboration across organisations and throughout the supply chain (Towill, 1997; Handfield and Nichols, 1999; Christopher, 2000; Simchi-Levi et al., 2002; Stratton and Warbuton, 2003). It means that supply chain management requires intemal (intra organisational) and extemal (inter organisational) integration (Stevens, 1989). So, the role of supplier and supply management practices is relevant in this context.

However, the integration of supplier in supply chain has not run the same course in all industries, and notable differences are observed anong automotive or aerospace industries and other industries like fashion, consumer electronics, personal computer, etc. (Ponce and Prida, 2006) This study sets out to examine these differences and explain their causes, using the experience of two Spanish industry leaders, in supply chain integration: the aircraft and the automotive industries. As a result of the research study, a set of supply practices common to both of these industries was identified. These practices revealed a change of the current supply management paradigm, which can be extrapolated to other industries. Besides, there have been different sets of contingent practices for each industry identified, which suggest the interest of developing new specific management supply models for each industry. The main contribution of this paper is to provide specific models to help define supply management policies in an integrated manuer with the supply chain for each industry studied. Both these models and their respective probable pattems of evolution over time are presented in this paper.

The paper is structured in seven sections. Following these preliminary remarks, the research approach is presented in Section 2. Then, in Section 3, a description of the supply management practices in two relevant Spanish industries is summarised. As a result of this study, a paradigm shift in supply management practices has been confimed, and some common 'best practices' in supply management are identified in Section 4 . Section 5 presents the contingency factors identified that suggest the need for a specific supply management model for each industry. In Section 6, the strategic supply management models specific for each industry are proposed (the main purpose of the research work presented in this paper), and the probable future evolution for each model is put forward. Finally, Section 7 presents the main conclusions of this study and some possible opportunities for further research.

\section{Research approach}

Since the aim of this research was to develop a theoretical supply management framework to help companies manage logistic procurement processes from a supply chain management approach (nowadays, in the authors' opinion, there is not a consensual framework for this), the research method adopted should involve an in-depth knowledge of supply management practices. The case study methodology recommended by Yin (1984), Bourgois and Eisenhardt (1988), and Eisenhardt (1989) was deemed adequate for this purpose. The comparative case study approach, as used in this study, provided the researchers with a variety of valuable views from the many managers involved, and enabled them to know 'how' and 'why' these supply management practices had been adopted. Yin (1984) considers this methodology to be very useful when the research aim is to answer 'why' and 'how' questions. In this study, the authors have analysed and compared two industries, using, among others, the experience of two Spanish industry leaders. The authors are of the opinion that the findings achieved and 
the practices identified revealed a change of the current supply management paradigm, which can be extrapolated to other industries, such as personal computer. This methodology has also been greatly endorsed by operations management researchers (Voss et al., 2002). The process followed to design and implement this methodology was adapted from Yin (1984), and it is shown in Figure 1.

Figure 1 Methodology approach adopted (see online version for colours)

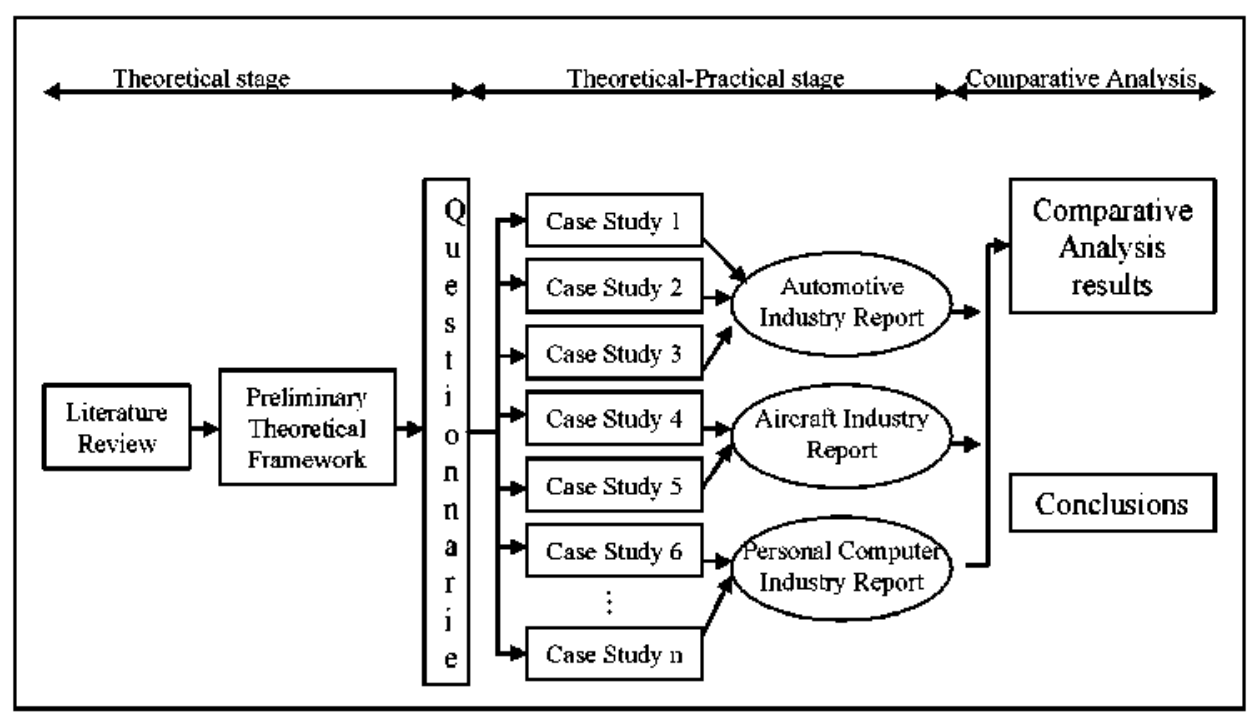

The research method began with a literature review (scientific journals, conference proceedings, case studies, white papers), examining the supply management practices of the automotive and the aircraft industries. The review served two purposes. First, it assisted the researchers in identifying the characteristics of the supply chain and the supply process, and how and why this supply management practice was adopted. As a result, a preliminary theoretical framework was developed to guide researchers in this study.

Once the literature review had been completed, the next step was to prepare the case studies, for which selecting the appropriate cases were of paramount importance. Eventually, a group of representative Spain-based companies from the car industry (one manufacturer and four first-tier suppliers) and the major Spanish aircraft company were selected. To address this step, the researchers visited these companies to interview their respective managers responsible for procurement, logistics, operations (production) and information systems. To maintain data consistency and gather as much detailed information as possible, a semi-structured interview approach was employed (Yin, 1984). Previous related research had already employed questionnaires (Gebauer and Buxmann, 2000 , among others). These were useful references for preparing the questionnaire for the case studies. The literature review led to the identification of some preliminary relevant procurement practices that were the basis to make a preliminary questionnaire, which was used in the first two interviews. To accomplish this preliminary study, the researchers visited two companies to interview their respective responsible managers for procurement, logistics, operations (production) and information systems. 
With the feedback from the first two interviewees, the questionnaire was refined and an eventual version was obtained to carry on the rest of the interviews for the case studies. Four managers from each company were interviewed. These were the persons responsible for operations (production), logistics, procurement and infonnation systems. Since each interview was roughly $1 \mathrm{~h}$ long, the total amount of time devoted to each company was approximately $4 \mathrm{~h}$. Most of the times, the researches were shown around the facilities. After gathering and analysing the information, those point that need some clarification were addressed via telephone with the corresponding interviewee. With all the information from the previous stages, a report was drawn up for each industry, and a comprehensive outlook regarding the cument situation of supply management was obtained.

The questionnaire consisted of the following different parts:

- basic company infonmation: size, gross sales. gross purchases

- competitive strategy

- intra-organisational and inter-organisational infonmation systems

- distribution process: delivery systems. kind of deliveries, delivery frequency

- production process: Engineer To Order (ETO). Assembly To Order (ATO), Make To Stock (MTS). etc.). production planning systems, integrated manufacturing systems

- procurement process: outsourcing, number of suppliers, relationships, supplier agreements. supplier selection process. supplier negotiation information exchange, etc

- procurement logistics: collections. ransport. delivery frequency, etc.

- supplier process control.

The study was complemented with the managers' statemems at several conferences organised by ODETTE (the association of automotive industry groups) and ATECMA (the Spanish member of the European Association of Aerospace Industries).

After identifying the most relevant supply management practices in the two chosen industries from the case studies (described in detail in Sections 3 and 4), the cases were thoroughly compared (Section 6) from which some remarkable conclusions were drawn (Section 7).

\section{Supply management practice description in two relevant industries}

In the following subsection a description of the most relevant supply management practices within the automotive and the aerospace industries is presented.

\subsection{Brief description of the Spanish automotive industry}

In recent years. car manufacturers have focused on their internal capabilities, namely designing, assembling and selling the finished vehicle. satisfying customer demands in tenms of perfonmance. qnality, delivery times and market service standards. 
This strategy has led them to investigate and even to anticipate market trends and, at the same time to manage the links in the supply chain to assure the standards of their product in a competitive world market in logistic, economic and technical terms.

Nowadays, automotive companies outsource somewhere between $60 \%$ and $80 \%$ of the final product cost (Schary and Skjott-Larsen, 2001, p. 180). Besides, more and more complex components of the final product are now subcontracted. In consequence, every leading car company has devoted a large amount of effort and resources to the rationalisation of their suppliers and to the technological integration by: modularising their products (Sako and Warburton, 1999), developing shared product designs, introducing Just-In-Time (JIT) component deliveries (Ansari and Modaress, 1990), promoting the creation of supplier parks, etc.

Spanish-based car-makers' daily production ranges from several hundred to several thousand units. Indeed, Seat (Martorell. Barcelona) produces approximately 2000 vehicles per day, whereas Peugeot (in Villaverde, Madrid) produces around 700 and Daymler-Chrysler 450 vans per day in Vitoria. Each vehicle requires $3000-4000$ parts, being already assembled parts that suppliers deliver to the corresponding manufacturer. These figures reveal to what extent part shipping is a major concem and thus, transportation costs and supply management are of paramount importance. Over the last decade, great logistic cost reductions have been achieved, in terms of shipping, reception and storage, handling and delivery). In an assembly plant within the automotive industry, logistic costs account for $5-7 \%$ of the total costs. Therefore, a $10 \%$ reduction of those costs would highly affect the benefits.

In this situation, procurement is becoming growingly important in both terms of cost reduction and products and services improvement. So, innovative procurement practices have been adopted in this industry. The following subsections include a brief description of the main practices adopted in recent years.

\subsubsection{Rationalisation of the supply chain}

The industry has faced this new context by means of building a network of hierarchical relationships: the manufacturer or final assembly plant, the first-level suppliers, and the second and lower-level suppliers (Sako and Helper, 1998; Nishiguchi, 1994).

Figure 2 shows a simplified diagram of the network of relations between automobile suppliers and manufacturers, and the materials and infomation flows along the logistic chain.

As shown in Figure 2, the manufacturer or final assembler has played a key role in the integration of the supply chain, imposing changes in the relationships with its suppliers. They lead and organise the process of integration of subassemblies in the final product, and the first-tier suppliers become responsible for organising teclnnological and logistical subsystems (Lannning, 1993, p.188). As a result of this increase in responsibilities of the first-tier suppliers, the main assemblers maintain direct relationship only with these suppliers

These first-tier suppliers often purchase their components from local manufacturers at a lower level of the supply chain. Given the universality of the process to manufacture those components (casting, stamping, plastic injection, etc.), if lower-level suppliers incur in quality deficiencies, price increases or service deficiencies, they may be easily replaced (Camuffo, 2002). That is the reason why relations with these lower-level 
suppliers are unstable. This policy, along with the lower technological level of these small firms, hinders the integration of the supply chain.

Figure 2 Snpply chain in the automotive indnstries (see online version for colours)

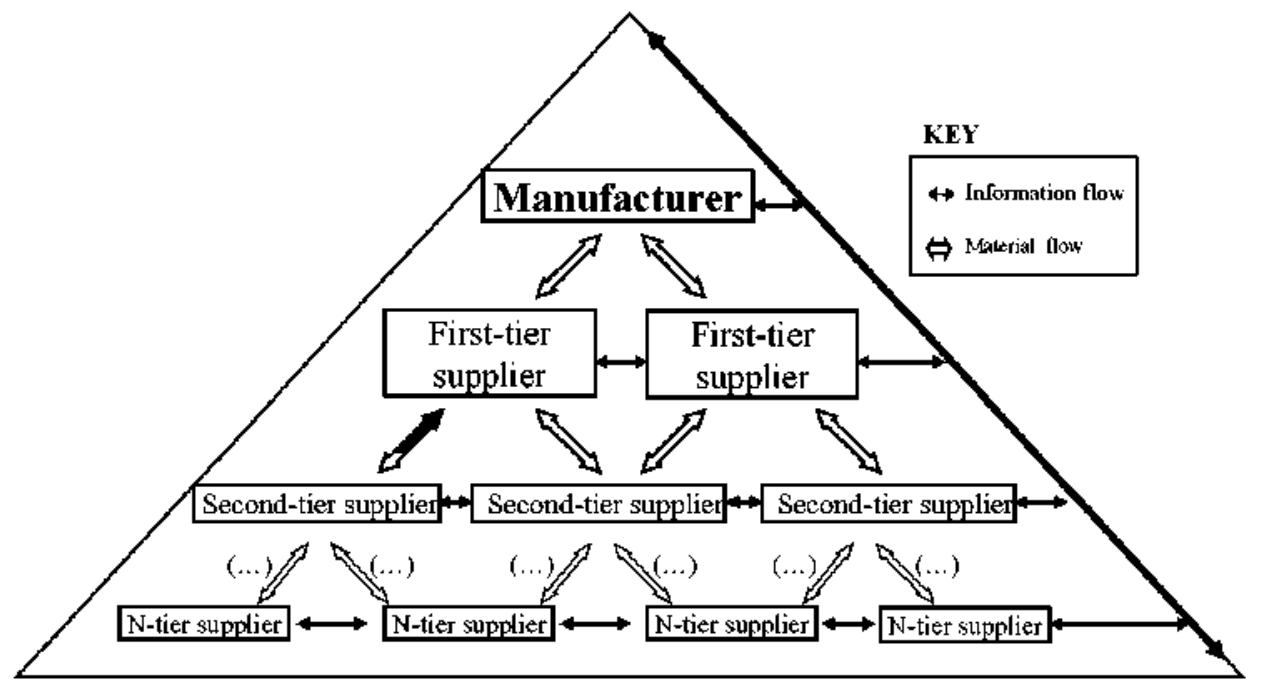

\subsubsection{Supplier relationships}

One of the main consequences of this new configuration of the supply chain in this industry is the dramatic reduction in the number of first-tier suppliers that manufacturers work with (Veloso, 2000; Hahn et al., 2000; Nishiguchi, 1994; Hines, 1995). Veloso's study shows a reduction from 800 to 150 in six years (Veloso, 2000). In the work of Lapiedra and Smithson (1998, p. 137), one of the SOGEDAC managers (Spanish Peugeot and Citröen supply head) reveals that since collaborative relationships with their suppliers were initiated, the number of suppliers had been reduced from 750 to 120 . As to this tendency, Renault's objective was to have only $350-400$ suppliers by 2000 .

Likewise, first-level suppliers are adopting this same policy and intend to reduce the number of their suppliers per component (their suppliers are the second-level suppliers represented in Figure 2), as the field study carried out for this research reveals. Along with this reduction in the number of suppliers, closer and more durable relationships are established. A small number of suppliers permit devoting more attention to them, which may mean cost and price reductions as well as improvements of the suppliers' facilities. This policy leads to keeping only the best suppliers.

Supplier number reduction is one of the aspects of the ongoing shift towards a model based on collaborative relationships between suppliers and manufacturers. This type of relationship enhances information exchange and promotes lasting commitment among actors (Nishiguchi, 1994). Besides, these collaborative relationships between first-tier suppliers and manufacturers are even more effective when suppliers are located in the supplier parks by the manufacturer's facilities. When that happens, parts are supplied by only one supplier, and relationships become even tighter. Some suppliers (Delphi, Johnson Controls, etc.) even cooperate with the manufacturers in developing and engineering new products (Sako and Helper, 1998) 


\subsubsection{JIT purchasing}

The rapid adoption of the JIT philosophy in this industry constitutes evidence of the quick diffusion of new demands for the whole supply chain in matters of quality. delivery quantities and times. new types of reception of materials, etc. (Prida, 1991). Main features of JIT purchasing practices are: single supplier per item, long-tenm supplier relationships. and small and frequent deliveries.

\subsubsection{Information exchanged}

Today, there is no doubt that effective integration needs a reliable and efficient interchange of technological and logistic data to maintain the new kind of relationship. The main European assemblers lead the ODETTE programme of Electronic Data Interclange (EDI) from the 1980s, and today nearly all first-lier suppliers use this system to interchange iufonmation with the main assemblers. However, its use by first and second-tiers is still very low in the European industry (Aufac. 2001).

Another initiative promoted by ODETTE in the car industry has been the use of European Network Exchange (ENX), analogous to the North American project Automotive Network Exchange (ANX), launched in 1998 (Garretson and Mines, 2000). ANX is an extranet infrastnicture supported by a Virtual Private Network (VPN) that euables manufacturers to link with the suppliers in conjunction with their Intemet Service Providers (Brennan, 2000). In Febnary 2000, the big manufacturers (Ford, General Motors, DaimlerChrysler, and later Nissan and Renault) launched COVISINT: a business-to-business vertical global poral (Covisint Solutions, 2002). The need for visibility and collaboration throughout the automotive industry can be, in part, solved by using internet-based teclnology solutions, which also represent an opportunity for adding value to automotive suppliers and manufacturers. Nevertheless. this imitiative has not yet been extended. and manufacturers and first-lier suppliers are still using EDI for their infonmation exchanges (Aufac, 2001).

\subsection{Brief description of the aircraft industry}

The aircraft industry has an oligopolistic market structure characterised by high-end technology and uncertain demand, which poses high financial and market entry banriers (Tyson, 1992). Small series and quasi-craft production, high-quality standards and a long time-to-market are characteristics of the very complex production process.

The production cycle of the aircraft industry is typified by the wide range and number of components needed to manufacture an aircraft (over one nillion). These components have different and often very long lead times (Esposito and Passaro, 1997).

In this industry, modularity is not as frequent as in the autonotive industry because the progrannne contracted with the final client is made to measure (quasi-craft production), and depends on whether the standard subsystems can be adapted or must be developed in collaboration between the leader of the progrannne and the developer of a sub-system. The relationship between these companies extends from the design and manufacturing to after-sales logistic support, and is maintained throughout the service life of the plane. 


\subsubsection{Rationalisation of the supply network}

Big manufacturers tend to subcontract sub-systems that are more complex and bigger than before. Suppliers that provide these sub-systems also subcontract parts and components (Humphreys et al., 2000). These trends highlight a tiering process in the supply chain that can be found in other industries such as the automotive one (Lamming, 1993; Nishiguchi, 1994; Sako, 1992). The supply chain in the aircraft industry may be seen as a scaled network in which vertical connections exist at different levels (as in the automotive industry), and horizontal connections exist between companies of similar weight and importance. Collaborative relationships between competitors to benefit from the enormous cost of development are frequent (Kearny, 1998).

Figure 3 shows a typical supply network for the development and construction of a programme of airplanes. This figure illustrates the hierarchical relations between companies at different levels and also their relationship of cooperation. The main assembly plants (Boeing, Airbus, Mc Donnell Douglas, EADS) are usually at the top of the supply network, but these companies may act as first-level suppliers in other programmes.

Figure 3 The scaled network of supply in the aircraft industry (see online version for colours)

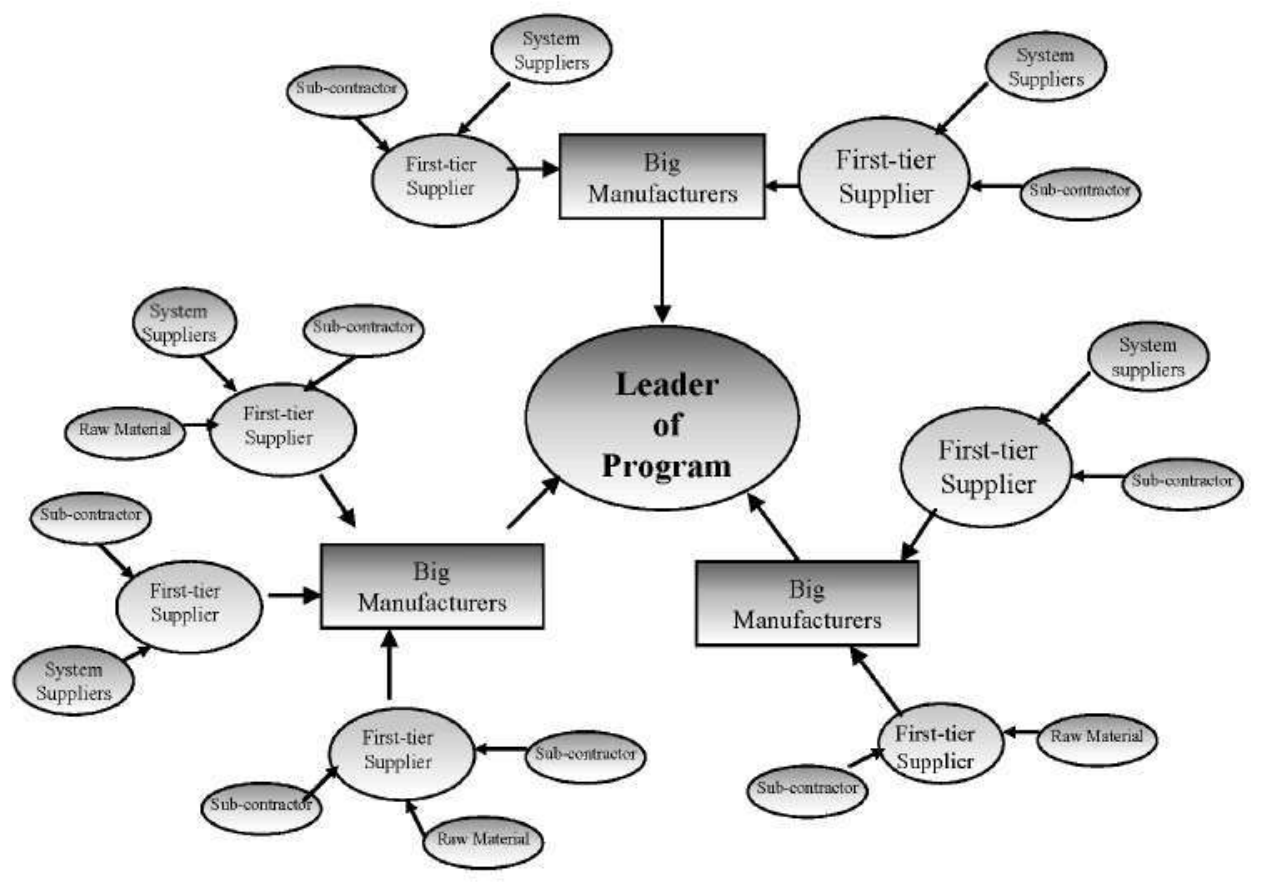

The first level in the scaled network of supply includes big companies that manufacture and assemble complex parts and components and deliver complete systems (EADS/CASA, Alenia, Aerospatiale, Alfa Avio, etc.), and these companies may also act as leaders of programmes of smaller dimension. They have to handle a complex network of relationships. They receive information on parts and components to be produced from the leading firm, buy the raw materials from suppliers certified by the leading firm, 
and select the second-level firms to which part of the production process has to be subcontracted (Esposito and Passaro, 1997).

The companies at the second level in the supply chain are the suppliers of standard sub-systems, sub-contractors or suppliers of components and raw materials. Those that supply sub-systems (engines, landing gear, electric installations, etc.), and some of the raw materials (for example, conposites), usually have their own technology and a great power of negotiation because there are few in the global market.

The other suppliers at this second level, the subcontractors, are usually medium or small companies which work with specifications, technical service, and sometimes materials and production technology provided by their clients, the first-level companies. Simple pieces (screws, rivets, bolts, etc.) and other raw materials are purchased in the market.

The aircraft industry calls for very special attention to quality, security and reliability that lead to a strict control of technical specifications in design and manufacturing, and sometimes the big manufacturer assumes the responsibility of assuring and demonstrating these controls. So, the purchasing staff must be highly trained to handle the complexities of technical specifications and to participate actively in the definition and selection of parts purchased. Homologation is a complex task in this industry.

A brief description of some important procurement practices is provided in the following subsection.

\subsubsection{Supplier relationships}

The product cannot be modulanised into standard sub-systens with connnon interfaces, and this limits the flexibility to develop and manufacture parts independently. So, an integral design is adopted. The stability and complexity of the supply chain depends on the technological complexity of the product and of the manufacturing process. In this industry, these complexities restrain the capacity of influence of big assemblers on the supply network.

However, the integration of the suppliers at every stage, from that of design right through the construction, has long been the recognised procedure, made inevitable by the integral nature of aircraft design. Even the after-sales service has come to be integrated right from the design stage. In fact, the supply chain includes the training of service staff and assistance in all the activities of maintenance throughout the service life of the aircraft. Rossetti and Choi (2005), in a recent study about strategic sourcing in the aerospace industry, argued that supplier flexibility capability plays a crucial role in sole sourcing agreements.

\subsubsection{JIT purchasing}

Here, the product is a technically complex unit, and the flow of components is small and imegular from widely distributed suppliers. The application of some concepts of the JIT philosophy is not as practicable as in the automobile industry (Ponce and Durán, 2001).

\subsubsection{Information exchanged}

Currently, the logistic coordination of the flow of materials has been managed with the support of Enterprise Requirements Planning (ERP), business-integrated computer 
system solutions, used by big and medium manufacturers in these industries. This common practice has led to reengineering the supply chain to ensure a centralised-decentralised policy of decisions of procurement in centres of manufacturers and suppliers at a distance.

The adoption of EDI systems of communication has been slower than in the automobile industry, doubtless because of the intermittent flow of the materials and the complexity of the information to be exchanged. In September 2000, the aerospace and defence industry launched the vertical electronic marketplace called exostar.com. Exostar's internet-based tools provide customised solutions (e-sourcing, e-procurement and e-collaboration solutions) for every segment (manufacturer, tier one, govemment, small and medium-sized enterprises) of this industry.

\section{Paradigm shift in supply management practices}

The research study presented in this paper shows an important shift in supply management practices, which has occurred over the last decades. The conventional model focused on the administrative efficiency of purchasing, more concerned with reducing material costs (through supplier negotiation) than with other factors (such as quality, lead times or market service patterns). That former model is still used in many companies, especially in those that sell commodities. Nevertheless, it is deficient in the current environment, especially for strategic sourcing. The authors have identified five relevant practices that competitive companies must adopt and enhance if they are to improve their relationships with their suppliers. Figure 4 shows schematically the most relevant shifts identified.

Those practices are interrelated with one another, as shown in Figure 5.

Figure 4 Paradigm shift in supply management in recent years (see online version for colours)

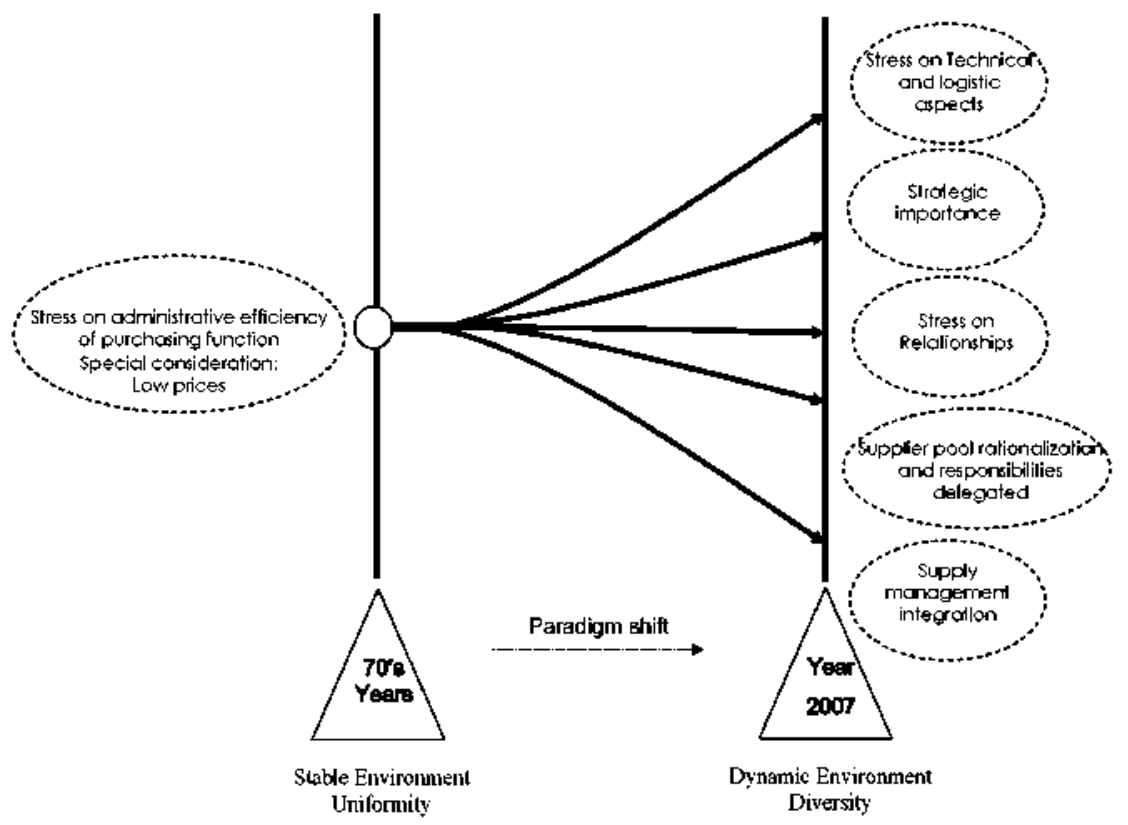


Figure 5 Relationships among supply management practices (see online version for colours)

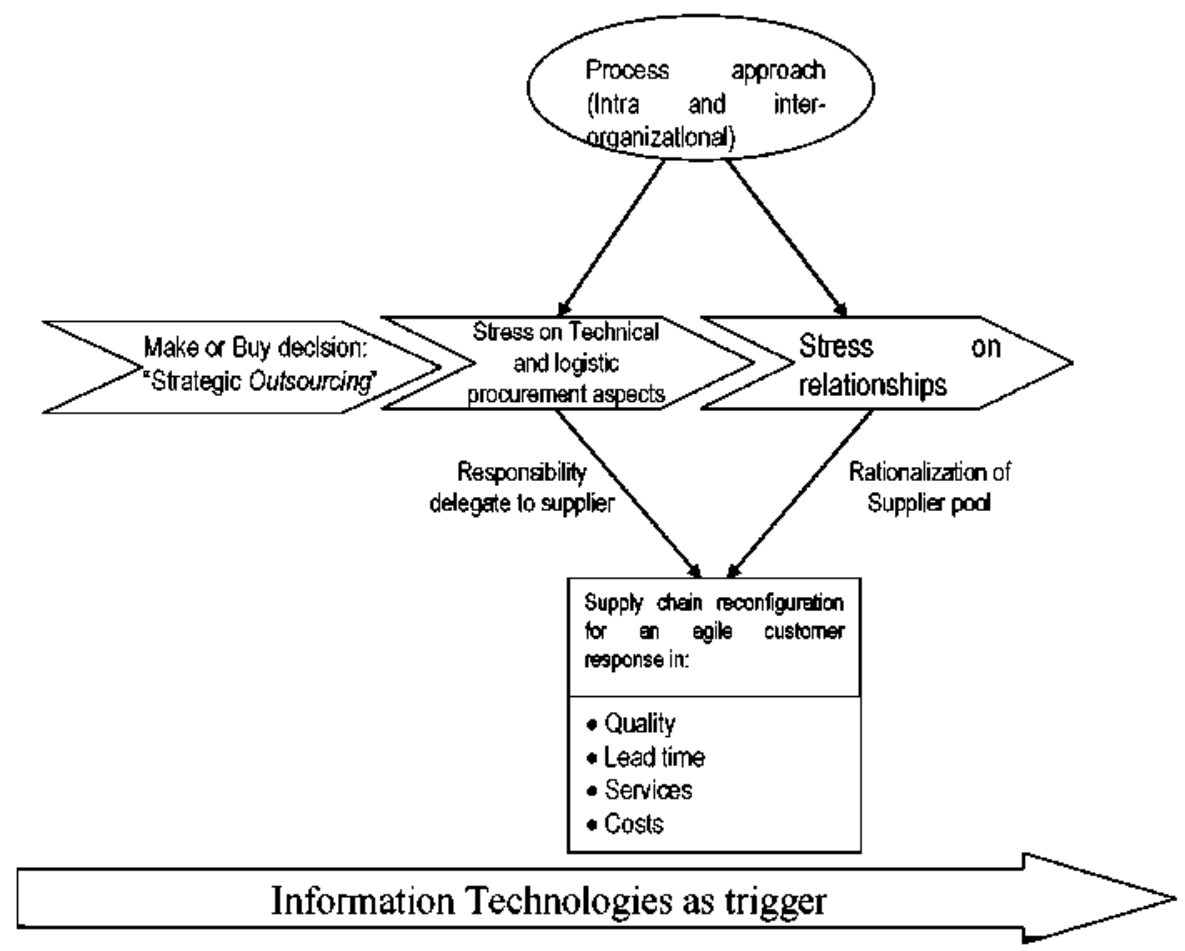

Regarding the make or buy decision, most companies opted for adopting strategic outsourcing. The relevance of the logistic dimension of procurement derives from the fact that a larger number and more complex components are subcontracted to other companies.

Likewise, technical aspects are also more relevant in supplier negotiations. So, the management of supplier relations is more important in the current environment than it was used in the previous model. A process approach is needed instead of a departmental or functional approach, because supply chains are expected to respond dynamically in terms of quality, lead times, costs and services.

\section{Industry contingency factors identified}

According to Fisher (1997, p.106), each product requires a specific supply chain. This author states that "the first step in devising an effective supply chain strategy is to consider the nature of the demand for the products one's company supplies". Many aspects are important, for example, product life cycle, demand predictability, product variety, and market standards for lead times and services. Products can be categorised into two groups according to their demand patterns: they can be either primarily functional or primarily innovative. Each category requires a distinctly different kind of supply chain. Functional products satisfy basic needs, which do not change much over time; they have stable, predictable demand and long life cycles (a similar classification was previously proposed by Kraljic (1983)). An efficient supply chain is adequate for 
these products; almost exclusively focused on minimising physical costs (production, transportation, storage). Regarding innovative products, they present unpredictable dernand patterns, high variety and short product life cycles (usually just a few months). So, market-responsive supply chains are needed for these products. Figure 6 exhibits a matrix to summarise the ideal supply chain strategy. The four cells represent the four possible combinations of products and priorities.

Figure 6 Matching supply chains with products (see online version for colours)

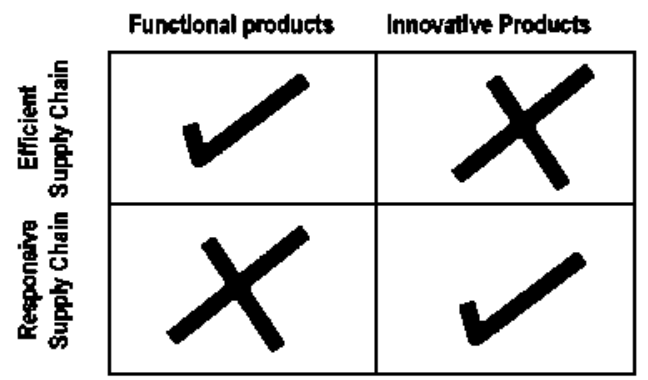

Source: Fisher (1997, p. 109)

Some products, such as personal computers or automobiles, could be functional or innovative. This situation entails a high risk of selecting the wrong supply chain. A lean, efficient distribution channel is exactly right for functional cars but totally inappropriate for innovative cars (according to Kraljic classification), which require inventory buffers to absorb the effects of an uncertain demand (Fisher, 1997). The most efficient place to put buffers is in parts, but doing so directly contradicts the JIT principles that automakers have so vigorously adopted in the last decade. Similarly, im the computer industry, depending on whether companies offer their products, as either functional or innovative, according to Fisher (1997) supply chain ought to be respectively effective or responsive to market changes. The aircraft industry defies classification within Fisher's matrix. In this case, products may be tagged as iunovative, because of both their high variety and variability. But, they are highly complex and are quite long-lived (13-20 years), making them unsuitable for agile or sensitive supply chains recommended for innovative products.

According to Christopher (2000), the type of supply chain that companies should choose depends on three factors, namely product variety, product variability and demanded volume. This author sustains that supply chains are to be agile in nnpredictable envirouments, characterised by a volatile demand and high variability of product demand (as is the case of personal computers). Van Hoek et al. (2001) measures agile capabilities in the supply chain, and more recently, Pujawan (2004) presents a model for assessing supply chain flexibility. There are certain conditions where a lean approach makes sense, in particular where demand is predictable and the requirement for variety is low and volume is high - conditions in which Toyota developed the lean philosophy. The problerns arise when atternpting to inplement that philosophy into situations where demand is not that predictable: the requirement for variety is high and, consequently, volume at the individual Stock Keeping Unit (SKU) level is low. To face a high product variety, automotive companies adopted strategies built upon the concept of postponement (Hsuan, 1999, p.197) and thus could make their supply chains somewhat more flexible. 
According to Bowersox (1982), postponement is defined as a dimension of the sequence, timing and scale of operation necessary to support differentiated marketing. At the root of postponement is the economic principle of substitutability. In brief, the two notions of postponement are:

- postpone changes in form and identity to the latest possible point in the distribution system

- postpone changes in inventory location to the latest possible point in time.

Figure 7 represents Christopher's $(2000$, p.39) matrix.

Figure 7 Agilc or lean supply chains

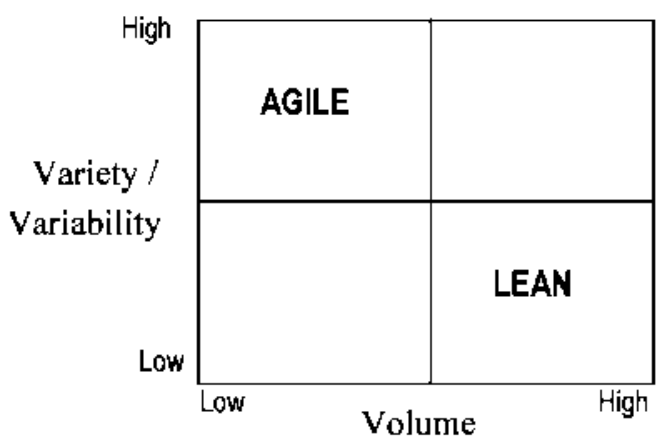

Source: Christopher (2000, p.39)

According to these authors' scheme and with the aim of including the specific features of every industry studied, the following contingent factors are identified in this study: product type; product life cycle; product complexity; technological changes pace; product architecture.

The supply chains of both industries studied have been characterised in terms of the mentioned factors.

\section{I Different supply chain strategy for each industry}

According to those factors identified by Chistopher (2000), 'lean' supply chains correspond to those used in the automotive industry, mainly by Japanese manufacturers. Nevertheless, Christopher's (2000) model does not properly reflect the tendency to introduce some degree of flexibility within the supply chain, which was identified in some automotive manufacturers. Additionally, the aircraft industry supply chain does not fit in that matrix either, since features such as low volume orders and high product variety occur in a non-volatile market (opposite to that of agile supply chains). Besides this, products are much more complex and life cycle time rather longer (13-20 years) than in other industries.

For this industry, a 'reliable' supply chain is recommended, capable of supplying high complex products, within the required quality standards and specifications, meeting deadlines and offering a reliable after-sale service. Following Fisher's (1997) list of contingent factors and his classification, products within this industry are 'unique'. 
The different studied supply chains are depicted in Figure 8 where they are labelled and located according to their respective strategy (agile, lean or reliable). The chart also includes the current evolvement of these chains. Several contingency factors have been used to classify and locate the chains: product type (unique, functional or innovative), life-cycle time, product complexity, product architecture (either integral or modular) and the pace of technological change.

In the $y$-axis, the pace of technological change and the product complexity are represented; the former increases upwards and the latter downwards. Similarly, in the $x$-axis, the product type and the life-cycle time (decreasing rightwards) are represented.

Figure 8 Supply chain strategy for each industry (see online version for colours)

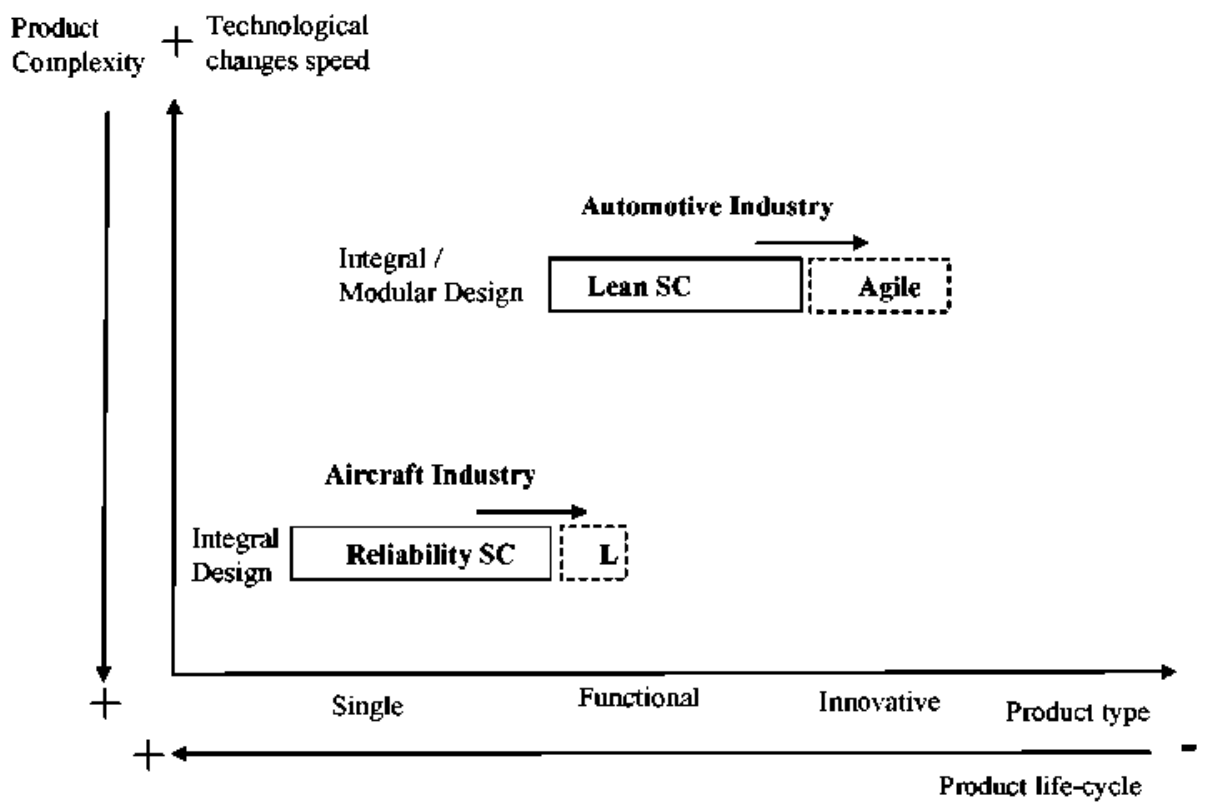

\subsection{Evolution of different supply chains}

The case studies not only revealed the features of the different industries but also let the researchers identify their respective tendencies (represented in Figure 8).

The aircraft industry, labelled as 'reliable', exhibited a slight tendency towards a rapidity-based model, which is a first step before attaining a 'lean' model. This tendency is represented in Figure 8 by means of a dotted line representing the lean model linked to the reliable model with an arrow. Proof for this evolution can be found in the introduction of a process approach, the adoption of process reengineering and JIT techniques by some companies and for some elements were possible (due to their demand and manufacturing features). These movements are mainly intended to reduce delivery and manufacturing times and, although not intended, this also implies cost reductions since inventory levels are reduced as well. Besides, as a rule, manufacturing responds to the Engineering To Order (ETO), and therefore, the product meets customer demands perfectly. There are drawbacks, nevertheless, since both receiving or not receiving orders may unbalance production systems. Regarding the last contingent factor (product architecture), 
the aircraft industry presents integral products altogether with integral product design. This feature highly influences the supply chain strategy, since the agile strategy is not suitable for this sort of design. Indeed, this strategy allows responding rapidly to demand changes, but when integral designs are adopted (where many parts are subcontracted) changes anywhere may affect to the whole and therefore changes cannot be done in a short period of time. In this case, the strategy to be followed is named 'reliable", where it is especially important to guarantee that all parts meet quality and technical specifications.

In its turn, the automotive industry is veering from a lean supply chain towards a hybrid strategy, where that part of the chain nearest to the customer follows an agile strategy. This evolution is represented in Figure 8 with an arrow from the current strategy towards the dotted area, symbolising the agile zone of the chain

This strategy is the result of applying the concept of 'postponement' to gain some degree of flexibility in the supply chain, so that it can adjust to the increase in product variety associated with more customised products. This approach consists of customising the product as near to the final customer as possible. By doing so, a major part of the assembly line is common to several models and can cope with a wide variety of products, derived from the possibility of introducing functionalities at the customer's request. This strategy is also employed to match more appropriately supply with customer demands. The Customer Order Decoupling Point Concept (CODP) helps understand this supply chain hybrid model. Upstream the CODP, the lean chain is managed according to forecast, whereas downstream the chain follows an agile strategy. This idea is represented in Figure 9.

Figure 9 Hybrid supply chain strategy differentiated by the CODP (see online version for colours)

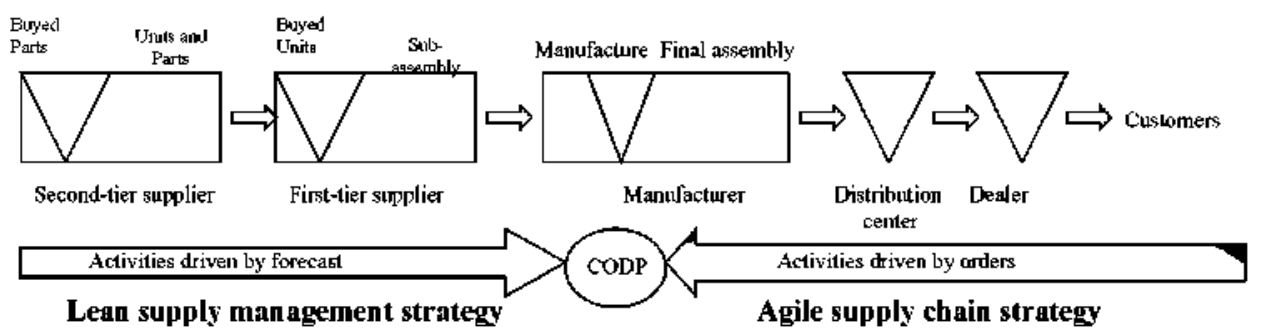

This approach facilitates a product 'mass customisation' strategy. This tendency, identified in the automotive industry, tries to adapt the product to the customer demands and offer it at competitive prices (Christopher, 2000; Bovet and Martha, 2000; Hsuan, 1999). The aim is to offer a greater variety of more customised products through flexibility and rapid responding.

In the automotive industry, product architecture takes the shape of integral design, although recently there is a slight tendency towards modularisation (Lynch, 1999). The shift towards a modular-based system implies changes in the architecture itself and in the supplier systems (Fujimoto and Takeishi, 2001).

Modular architecture presents advantages when it comes to adopting an agile strategy for supply chain management. This industry has experienced progress in this regard, although unevenly throughout different regions. This reveals that, either due to technological, functional or historical reasons, the current prevailing product architecture 
is integral rather than modular (for instance, components are barely standardised across products and companies) (Ulrich, 1995). Likewise, the supply strategy in this industry is mainly lean. Actually, modularisation is a slow, complex and often controversial process (for example, it may negatively affect manufacturers' capability to differentiate their products from their competitors).

This term may apply to product design, technology, equipment manufacturing job design, etc. Automotive design and manufacture entail more complexity than for other products, such as personal computers (in terms of safety, logistic aspects, etc.), which accounts for the difficulties in adopting a modular approach in this industry. All these features led to the conclusion that currently there is no modular architecture within the automotive industry (Camuffo, 2002).

\section{Strategic supply management practices framework}

The models proposed for procurement strategic management in the automotive and the aircraft industries are presented in this section. These models are integrated in the strategic supply chain specific to each industry. A summary of these models is shown in Figure 10.

Figure 10 Strategic supply management framework (see online version for colours)

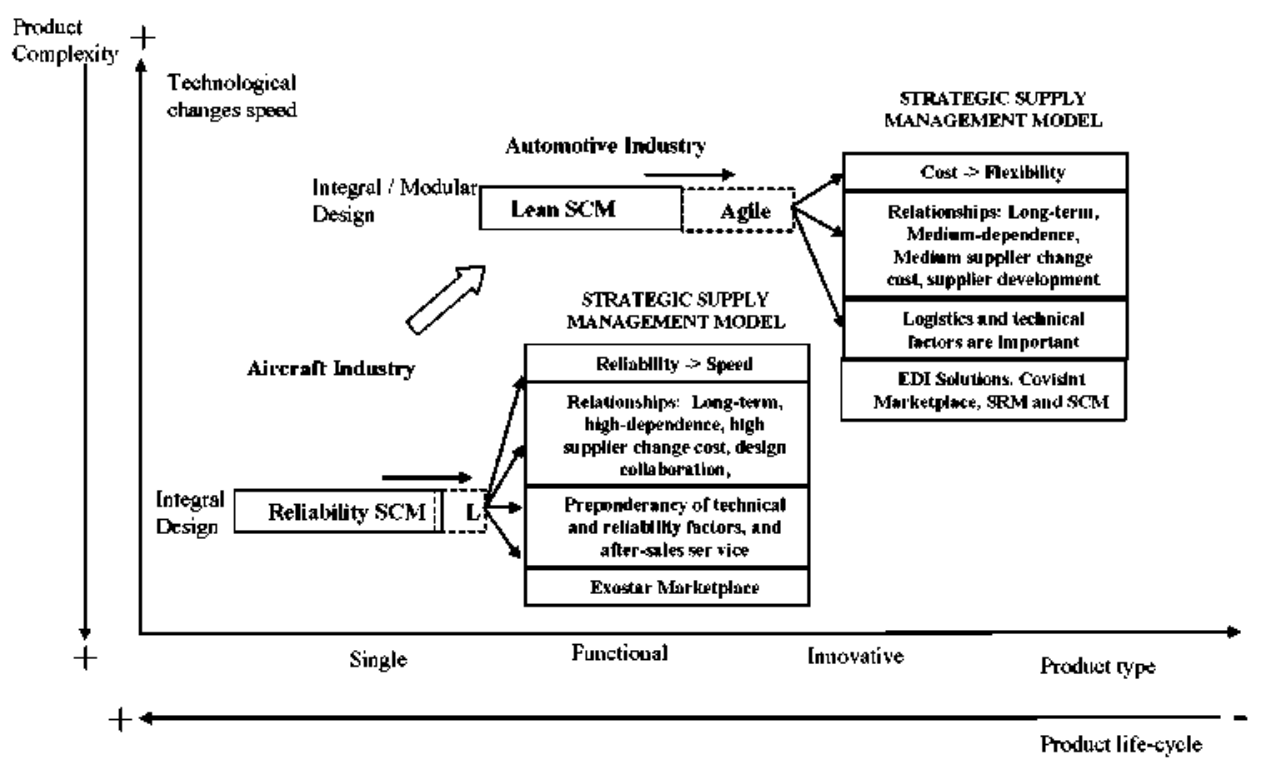

Four textboxes summarise the characterisation of each industry. The first textbox of each strategic supply model represents its respective strategy (in line with that of the supply chain).

The second one includes a brief description of those eligible practices to supplier relationships.

The third textbox identifies which is the predominant strategic dimension (either technical or logistic) for each case. Needless to say, the more complex the product is to 
buy, the more relevant the technical dimension becomes. Regarding the reaction speed of supply chain, the logistic dimension is more important.

Finally, in the fourth textbox, the e-conmence solutions employed in each industry for relating to suppliers can be found.

It is noteworlly that the depicted models are dynamic, and tend to evolve towards the next stage. The dynamic nature of the models has been represemed by means of arrows linking each model to the model it tends to. Of course, evolving does not mean adopting the very same supply practices in all industries since, as noted, contingem factors exist that would prevent that from making sense and, thus, occurring.

The study of these two industries has resulted in a conprehensive outlook for each case, where an evolving pattem can be distinguished and characterised in each case.

\section{Conclusion and future work}

The set of supply practices connnon to the two industries identified in this paper revealed a change of the current supply management paradigm. The survey and analysis of these industries has confimmed the strategic importance of supplies and the need for an integrated approach of supply managemem, both in terms of internal processes and in ternns of extemal suppliers. Another important factor identified in the two industries is managing relationships with suppliers properly, so that supply chains are more stable and can add value to the final consumer. All these changes have occurred along with a reconfiguration of the supply chain consisting of delegating responsibilities to first-tier suppliers and in reducing the number of suppliers, with whom more tight and collaborative relationships are established.

Additionally, the supply strategy must integrate into the company's strategy and this, in tum, into that of the supply chain. The study has proved that supply chains of different industries require, and actually adopt different strategies, which require different supply strategies for each industry as well. Therefore, it can be concluded that there is not a unique model for supply management, valid for all industries, given the current environment.

The study has revealed that companies employ different practices to adapt to the particularities that the environment and the industry they operate in impose upon them. Although some of the identified tendencies in supply management are connmon to the two industries, the motivation for applying them are usually different. From that perspective, contingent factors exist that condition to what extent different practices become widespread across industries. Some of these factors are: constraints imposed by technical complexity, product architecture, technological and organisational standardisation, leadership to establish and spread their use.

Finally, the new framework for supply management, based on collaborative relationships with suppliers, should not be regarded from an individual perspective, focused on analysing independenly each client-supplier relationship. Supply management must comespond to an integrated approach within the logistic process (supply chain). 
The availability of new technological solutions opens novel conceptual frameworks for supply, but it does not necessarily press companies to adopt them. Adopting new solutions to facilitate conmunication between suppliers and clients within procurement and supply areas is highly conditioned by the company's supply model.

As for further developments, it would be of great interest to extend the comparative study to other industries. Analysing new industries may improve the generality of the presented model. It could also provide with new pattems for supply chain models oriented towards achieving specific and differentiated capabilities.

\section{Acknowledgement}

We are grateful to the managers who have contributed to this study.

\section{References}

Anfac (2001) Resultados del estudio sobre el impacto del comercio electrónico en el sector del automóvil español, Anfac, Odette España and Ministerio de Ciencia y Tecnologia, Madrid.

Ansari, A, and Modanes, B. (1990) Just in Time Purchasing. Free Press, New York.

Ansoff, H.I. (1970) Corporate Strategy, Pelican, London.

Bourgois, L. and Eisenhardt, K. (1988) 'Strategic decision processes in high velocity environments: four cases in the micro-computer industry', Management Science, Vol. 34, No. 7, pp.816-835.

Bovet. D. and Martha, I. (2000) Value Nets, Breaking the Suppty Chain to Unlock Hidden Profits, Jolm Wilcy \& Sons, New York.

Bowersox, D.I. (1982) "Emerging from the recession: the role of the distribution manager", Focus 1, July-August, p.2.

Brennan, M. (2000) ANX Laumches Auto Industy Portal Site. Michigan Teclmologv New's, http:/www.mileclmews.com/new/show_article.asp? category= 34\&id = 24, 9 Angust.

Burt, D.N. and Soukup, W.R. (1985) 'Purchasing's rolc in new product development', Harvard Business Review, No. 63, September-October, pp.90-96.

Camuffo, A. (2002) Globalization, Outsourcing and Modularity in the Auto Industry, URL, www.sses.com/public/events/euram/complete_tracks/modularity_and_division/camuffo.pdf

Christopher. M. (2000) 'The agile supply chain: competing in volatile markets', Industrial Marketing Monagement, Vol. 29, No. 1, pp.37-44.

Coase, R.H. (1937) 'The nature of the firm', Econónica, No. 4, pp.386-405.

Covisint Solutions (2002) hup//www.covisint.com/solutions/prod, 30 Seplember.

Eisenhardt, K.M. (1989) 'Building theories from case study research', Academy of Management Revien, Vol. 14, No. 4, pp.532-550.

Ellram, L. and Carr, A. (1994) 'Strategic purchasing: a history and review of the literature', International Jounal of Purchasing and Materials Managentent, Vol. 30, No. 2, pp.10-18.

Ellram, L.M. and Billington, C. (2001) 'Purchasing leverage considerations in the outsourcing decision', European Journal of Purchasing and Supply Management, Vol. 7, No. 1, pp.15-27.

Esposito, E. and Passaro, R. (1997) 'Material requirements plaining and the supply chain at Alenia Aircraft', European Joumal of Purchasing and Supply, Chain Management, Vol. 3 , No. 1, pp.43-51. 
Fisher, M.L. (1997) 'What is the right supply chain for your product?', Horvard Business Review', Vol. 75, No. 2, pp. 105-1 16.

Fujimoto, T. and Takeishi, A. (2001) Molularization in the Auto Industrv: Interlinked Multiple Hierarchies of Product, Production and Suppliers Systems, IMVP Working Papers, URL, www.e.u-tokyo.ac.jp/itme/dp/dp70.pdf

Gadde, L. and Hakansson, H. (1994) "The changing role of purchasing: reconsidering three stralegic issues", European Joumal of Purchasing and Suppty Management, Vol. 1, No. 1, pp. 27-35.

Garretson, D. and Mines, C. (2000) The Net Revs Up Auto Making, Forrester, http://www. foresler.com/ER/Researcl/RepordSummary/0,13338,9484, FF.html, June.

Gebalker, J. and Buxmam, P. (2000) 'Assessing the value of interorganizational systems to support business transactions", Intermational Jounial of Electronic Commerce, Vol. 4, No. 4 , pp.61-82.

Halı, C.K., Duplaga, E.A. and Harley, J.L. (2000) 'Supply-chain synchronization: lessons from Hyundai Motor Company', Interfoces, Vol. 30, No. 4, pp.32-45.

Handfield, R.B. and Nichols, E.L. (1999) Introduction to Supply Chain Management, Prentice-Hall, New Jersey.

Heberling, M.E. (1993) 'The rediscovery of modern purchasing', Intemationat Joumal of Purchasing and Materials Management, Autumn, pp.48-53.

Hines, P. (1995) 'Network sourcing: a hybrid approach', Intemational Journal of Pwrchasing and Materials Management, Vol. 31, No. 2, pp.17-24.

Hsuan, J. (1999) 'Impacts of supplier buyer relationships on modularization in new product development', European Joumal of Purchasing and Supply Management, Vol. 5, pp.197-209.

Humphreys, P., McIvor, R. and McAleer, E. (2000) 'Re-engineering the purchasing function', European Joumal of Purchasing and Supply Monogement, Vol. 6, No. 2, pp.85-93.

Kearney, A.T. (1998) The Impact of Glabal Aerospace Consolidation UK Suppliers, A.T. Kearney Ltd., Loudou, http:/www, (a)akeancy .com

Kraljic, P. (1983) 'Purchasing must become supply management', Harvard Business Review', Vol. 61 , No. 5, pp.109-117.

Lamming. R. (1993) Beyond Partnership. Strategies for Innovation and Lean Supply, Preutice-Hall, London, p. 188.

Lapiedra, R. aud Smithsou, S. (1998) 'Auálisis del proceso de formación de una red de empresas: estudio de un caso en el sector del antomóvil", Revista de Economia y Empresa, Vol. 12, No, 33, pp. 127-141.

Lee, H.L. (2002) 'Aliguing supply cham stralegies with product uncertainties', Califonia Monagement Review, Vol. 44, No. 3, pp.105-119.

Lynch, T.M. (1999) Globalization in the Motor Vehicle Industry: Final Conference Summary, MIT-IPC Working Paper 98-0010.

Merli, G. (1994) Comakership (Fabricación asociada), Nueva Estrategia de Aprovisionamientos para la Fabricación, Díaz de Santos, Madrid.

Nishiguchi, T. (1994) Strategic Industrial Sourcing. The Japanese Advantage, Oxford University Press, New York.

Ponce, E. and Durán, A. (200l) 'Alternatives in information systems integration in inter-organizational concurrent engineering', in Baake, U.F., Herbst, J. and Schwarz, S. (Eds.): 8th European Concurrent Engineering Conference. Concurrent Engineering: The Path to Electronic Business, 18-20 April, SCS Publication, Valencia, pp.98-100. 
Ponce, E. and Prida, B. (2006) La logistica de aprovisionantentos paru la integración de la codena de suministros, Prentice-Hall, Financial Times, Madrid.

Prahalad, C.K. and Hamel, G. (1990) 'The core competence of the corporation', Horvard Business Review, Vol. 68, No. 3, pp.79-91.

Prida, B. (1991) 'The other side of ЛТ in snpply management', Production and Inventory Managentent Joumal, Vol. 32, No. 4, pp.1-3.

Pujawan, N. (2004) 'Assessing supply chain flexibility: a conceptual framework and a case stndy', Intenational Joumal of Integrated Supply Management, Vol. 1, No. 1, pp.79-97.

Pyke, D.F. and Johnson, M.E. (2003) 'Sourcing strategy and snpplier relationships: alliances vs. eProcnrement', The Practice of Supply Chain Management, Klnwer Publishers, Boston.

Quinn, J.B. and Hilmer, F.G. (1994) 'Strategic sonring', Sloan Management Review, Vol. 35, No. 4, pp. 43-55.

Reck, R.F. and Long, B.G. (1988) 'Purchasing: a competitive weapon', Jounal of Purchasing and Materials Management, Vol. 24, No. 3, pp.2-8.

Rossetti, C. and Choi, T.Y. (2005) 'On the dark side of strategic sonrcing: experiences from the arrospace indnstry", Academy of Management Executive, Vol. 19, No. 1, pp.46-60.

Sako, M. (1992) Quality and Trust, Inter-Fim Relations in Britain and Japan, Cambridge University Press, Cambridge.

Sako, M. and Helper, S. (1998) 'Detenminants of trust in supplier relations: evidence from the antomotive industry in Japan and the United Stales', Joumal of Economic Behavior and Organization, Vol. 34, No. 3, pp. 387-417.

Sako, M. and Warburton, M. (1999) 'Modularization and outsouning project. preliminary report of the European Research Team', MPV'Annual Forum, MIT, Boston, 6-7 October.

Schary, P.B. and Skjott-Larsen, T. (2001) Managing the Global Supply Choin, Copenhagen Business School Press, Denmark, p. 180.

Simchi-Levi, D., Kaminsky, P. and Simchi-Levi, E. (2002) Designing and Managing the Supply Chain: Concepts, Strategies and Case Studies, McGraw-Hill/Irwin, Boston.

Spekman, R.E. (1981) 'A strategic approach to procurement plauning', Joumal of Purchasing and Moterials Management, Winter, pp.3-9.

Stevens, G.C. (1989) 'Integrating the snpply chain', Intemational Jounal of Physical Distribution and Materials Management, Vol. 19, No. 8, pp.3-8.

Stratton, R. and Warburton, R.D.H. (2003) 'The strategic integration of agile and lean supply', Intenational Joumal of Production Economics, Vol, 85, No. 2, pp.183-198.

Towill, D.R. (1997) 'The seamless supply chain - the predator's strategic advantage', Intemational Joumal of Technology Management, Vol. 13, No. 1, pp.37-56.

Tyson, L. (1992) Who's Bashing Whom? Trade Confict in High Technology Industries, Institule for Intemational Economics, Washington.

Urich, K. (1995) 'The role of product architecture in the manufacturing firm', Research Policy, Vol. 24, pp.419-440.

Van Hock, R., Harrison, A. and Cliristopher, M. (2001) 'Measuring agile capabilities in the supply cham", International Joumal of Operations and Production Management, Vol. 21, Nos. 1-2, pp. $126-147$.

Veloso, F. (2000) 'The automotive supply cham: global trends and Asian perspectives', International Competitiveness of Asian Economies: A Cross-Countiy Study, Cambridge, September.

Venkatesan, R. (1992) 'Strategic sourcing: to make or not to make', Harrard Business Review, November-December, pp.98-107. 
Voss, C., Tsikriktsis, N. and Frohlich, M. (2002) 'Case research in operations management', Intemational Journal of Operations and Production Management, Vol. 22, No. 2, pp.195-219.

Williamson, O.E. (1975) Markets and Hierarchies: Analysis and Antitrust Implications, The Free Press, New York.

Yin, R.K. (1984) Cose Study Research: Design and Methods, Sage Publications, London.

\section{Websites}

Covisint, hHp://www.covisint.com/

Exostar, hHp://www.exostar.con/

ODETTE, http:/www odette.es/ 